\title{
A Structural Equation Modeling of Perceived Justice in Malaysian Telecommunication Sector
}

\author{
Shishi Kumar Piaralal ${ }^{1}$, Niriender Kumar Piaralal ${ }^{2} \&$ Muhammad Awais Bhatti $^{3}$ \\ ${ }^{1}$ OUM Business School for Open University Malaysia, Malaysia \\ ${ }^{2}$ University Utara Malaysia, Malaysia \\ ${ }^{3}$ College of Business, School of Business Management, University Utara Malaysia, Sintok-Kedah Malaysia, \\ Malaysia
}

Correspondence: Shishi Kumar Piaralal, OUM Business School for Open University Malaysia, Malaysia. Tel: 60-19-263-1571. E-mail: shishi@oum.edu.my

Received: June 30, $2014 \quad$ Accepted: December 17, $2014 \quad$ Online Published: January 14, 2015

doi:10.5539/ass.v11n4p77 URL: http://dx.doi.org/10.5539/ass.v11n4p77

\begin{abstract}
Perceived justice is one of important factor in previous studies of service recovery that influences satisfaction of service recovery. It can be assessed in two method namely uni or multi-dimensional. The objective of this research is to examine perceived justice measurement as uni or multi-dimensional towards mobile phone users in the telecommunications industry. Data analysis technique used was Structural Equation Model (SEM). The multi-dimensional nature of justice and satisfaction was verified based on confirmatory factor analysis. The measurement model of the hypothesized model confirmed the non-multicollinearity results among the variables. The findings show that the perceived justice measurement fits the data better in terms of multi-dimensional. The limitations of this studied noted and further research suggestions are also included.
\end{abstract}

Keywords: structural equation modeling, perceived justice, service recovery

\section{Introduction}

Perceived justice is a variable viewed very important in the study of service recovery related to satisfaction with service recovery understanding. The variable was presented as uni or multidimensional in most of the studies done by researchers in western countries. In Malaysia past researches on justice are limited to human resource areas only. There is limited study associated with service recovery in term of perceived justice variable measurement as uni or multi-dimensional context being carried out. This studied will verify whether perceived justice can be measured as uni or multi-dimensional toward mobile phone users in the telecommunications industry.

Customer right awareness has significantly increased in Malaysia The customers that have not satisfied with service raised the complaints to organizations and also highlighted to authorities or to third parties for instance the consumer association. For example Communications and Multimedia Consumer Forum of Malaysia had recorded nearly double the number of complaints from telecommunication subscribers in 2012 at over 1,100 cases compared with the 498 cases in 2011 (Tam, 2013). Competition among service providers in Malaysia telecommunication industry is severe. Therefore the service providers need to be continued inspire towards satisfying the customers (Business Monitor International, 2009). This is by building and maintaining high quality customer relationship to ensure continued loyalty (Shapiro \& Nieman-Gonder, 2006).

In Malaysia mobile market the main mobile network operators are CELCOM, MAXIS, DIGI and U-MOBILE. All the mobile network operators are regulated by the Malaysia Communication Multimedia Commission (MCMC). Based on MCMC report mobile usage penetration rate have increased from 9.8/100 per population in 1996 to 117.6/ 100 per population in 2011 (Soo, 2009; Business International Monitor, 2011). Recently there are 40 million subscribers with the penetration rate of mobile phone usage are 140/ 100 per population in beginning of 2013 (retrieved from http://www.budde.com.au). This penetration rate has reached above saturation point. Therefore the service providers have opportunities to offer a wide range of incentives to the mobile phone users. As the result change of present mobile network operators when the customer is not happy with the service will be reduced (Maxham \& Netemeyer, 2003). Furthermore the Malaysian mobile users are considered medium 
scale related to customer satisfaction and loyalty (Frank \& Sullivan, 2005). Medium scale refers to the mobile users that willing to change when required the mobile providers. The customers had put it off unless it was the last choice due to problem in changing numbers and notifying contacts when changing to another network (Seth, Momaya, \& Gupta, 2005).

Mobile Number Portability (MNP) introduction in late 2008 allow the mobile users to select or change mobile provider while maintaining their mobile number at any time (Business Monitor International, 2009). This has created new challenges for mobile providers in handling not happy customers. Competition will be fiercer with MNP gaining momentum due to lower cost and impact for changing mobile service providers. During the first month of MNP introduction about 86,636 mobile users had switched the mobile providers and expected 5 to 10 percent will make the change within a year (Yuen, 2008). It shows that the change of mobile service provider can be done easily when the customer never received the expected level of service.

According to Maxham (2001) the organizations need to be careful in handling service failure cases. Negative publicity that cause negative word of mouth can be spread thorough variety of different interactive communications channels (Crie, 2003). About 86 percent of failed service cases are still unforgettable even though occurred over five years ago. This will direct to defection (H. K. Hunt, D. Hunt, \& C. T. Hunt, 1988). Therefore relatively speedy and effective efforts are required to handle the poor service delivery in order to avoid negative impact to the organizations (Bodey \& Grace, 2006). The customer that experienced bad service and follow with poor recovery will cause customer not happy. Furthermore the loyal customer will be very angry and disappointed when the complaint was not handled properly and effectively. This will create chance for the customer to actively condemn about the organization (Heskett et al., 1994). Therefore service recovery is the main area for the organization to emphasize in satisfying the customer (Zeithaml et al., 1993). The well-established organizational strategies for appropriate service recovery efforts are required in handling complaints. This will help to bring back unhappy customer to the happy situation, but very few organizations have these strategies (Bitner et al., 1990). It is important for organizations to look into appropriate strategies to ensure customers continue to be loyal to them through customer satisfaction. The theme "Customer Satisfaction" has been a main priority for many successful organizations (Szymanski \& Henard, 2001) and customer satisfaction in today's business world equates to profitability. It is essential variable in the past studies on management field (Hansemark \& Albinsson, 2004). Besides that customer satisfaction being accepted in marketing practices as a central concept for all the activities of business (Anderson, 1994).

The initial research in service recovery has established a relation between complaint handling satisfaction and subsequent post purchase behavior and later directed to understanding how customers evaluate recovery experiences (Johnston \& Michel, 2008). Service recovery is considered as umbrella term. It is an organized attempt by an organization to retain client support through solving a problem following a poor service delivery (Nek Kamal, 2009). Restoring satisfaction of customers is important role that plays by service recovery effort (Lovelock, Wirtz, \& Keh 2002). According to De Run and Ting (2006) the main area that needs more attention by mobile phone network providers in Malaysia telecommunication industry is service recovery. This is due to the MNP introduction has lower the switching cost and barrier for mobile number change. Therefore mobile network companies need to take seriously the poor delivery of service and require in implementing an effective deployment of service recovery strategies urgently. In quality management service recovery is considered one of the elements that helped in maintaining the business link with clients (Boshoff, 1997). Service recovery tries to identify when failure occurs and tried to solve the service problems even before customers complain or leave with no satisfaction (Boshoff, 1997).

During recovery of service effort if the customer could not be recovered successful the customer may discontinue the business with the organization. This could resulted negative impact on organizational performance (Shapiro \& Nieman-Gonder, 2006). As a result managing the relation with customer is very essential in the organization. The understanding of service recovery effort influences is another main strategy for customer satisfaction. The perception of justice evaluation for the poor service occasion happen to customers is one of measurement for successful service recovery attempt (Kau \& Loh, 2006). The recoveries from service failure can be assessed by customer based on the perception of justice. This will impact the decision about customer satisfaction level with the type of recovery being offered. If the customer is satisfied, the level of trust and loyalty increased which will help to improve the organization business (Kau \& Loh, 2006; Weun, Beatty, \& Jones, 2004). For example, mobile network provider DIGI had an experienced of service failure in the prepaid segment and only a limited number of customer noticed and complained about the problems. The immediate action taken by DIGI was providing the prepaid customer with discount on calls for half day to pay damages for failed of service ("Half Price", 2009). This practice reflected an excellent service recovery. The mobile phone 
user might rate the organization highly on satisfaction with recovery and might have a positive impact toward trust, faithfulness and word of mouth.

The main obstacle for switching networks has been removed with the introduction of MNP. The service providers need to put more effort in preventing defection by improving and speeding the service recovery (Keaveney, 1995). In United Arab Emirates the Telecommunications Regulatory Authority has revealed that 61,000 customers had requested to switch mobile provider since mobile number portability (MNP) was introduced at end of 2013 and expected more customers in the coming months (http://www.itu.int). Based on this data the shifting of mobile network might occur due to the unhappy customers regarding the poor service recovery attempt on failed of services. Service recovery attempt towards customer satisfaction becomes a very important factor in handling the situation. In some previous studies, satisfaction with service recovery attempt was directly assessed based on perceived justice (Kau \& Loh, 2006; Smith \& Bolton, 1998). In a studied carry out by Weun et al. (2004) based on 1070 respondents from the hotel and mail order organizations in US concluded that relationship between distribute justice variable and service recovery satisfaction of customer was moderated by severity of service recovery factor. The findings also revealed that the correlation between interactional justice and service recovery satisfaction of customer not moderated by service recovery severity factor. Positive or negative behavioral outcomes namely trust, loyalty and word of mouth level is depend on perceived satisfaction of the customer with recovery of service as mobile network companies attempt to improve the poor delivery of service. Hence, this research paper objective is to examine the measurement of perceived justice either as uni or multi dimensions towards mobile phone users in the telecommunications industry.

\section{Literature Review}

\subsection{Customer Satisfaction}

Making customer satisfied and happy has become an important element for success of business organization in the competitive market (Johnston \& Michel, 2008). The Malaysian mobile network companies need to view the customers as appreciating assets and need to reduce customer imperfection, a decision by customer to discontinue buying services or goods from a particular company (Keaveney, 1995). One of the important approaches in business world that can be implemented in retaining and satisfying the customer during service problems is through recoveries of service (Swanson \& Kelly, 2001). The customers that are loyal are normally happy, costless to service, willing to give more time and help to support for the growth and provide new opportunities of business for the company (Levesque \& McDougall, 1993). They normally direct to cheaper marketing, improve operations efficiency and yield better profits (Dick \& Basu, 1994). It was suggested by researchers, 5 percent improvement in retention of customers will direct about 25 to 85 percent of profit margin increase and it depends on the type of business (Reichheld \& Sasser, 1990). The yield of better profits is basically can be happen in three approaches. The first approach is by obtaining new customers' organizations spend more than five times compare to retaining of old clients (Tse \& Wilton, 1988). Secondly, repeated and happy clients frequently not demanding on worker time because customers have reasonable anticipations and requirement based on past knowledge. This will help the workers become more efficient through involvement with the needs of customers' (Swanson \& Kelley, 2001). In last approach the economic benefits received by the company in term of growth performance are related to customer spreading positive word of mouth and loyal customer (Lewis \& McCann, 2004). Additionally, Zemke (1999) argue the unhappy clients possibly will tell about bad experience information to 10-20 people and will spread negative thought about the company.

\subsection{Distributive Justice}

Distributive justice focused on outcome and costs of parties that involved during a business transaction. From the complaint context view, distributions are considered as physical outcomes such as replacement of the product or money refund given to the complainer by the firm (Santos \& Fernandes, 2008). Distributive justice in the organizations related in terms of equality of opinion by workers in working place. The evaluation based on inputs by workers to outcomes ratio that organization offered (Niehoof \& Moorman, 1993). It was emphasized by Greenberg (2001) as the reaction of workers' towards treatment of equality or allocation of financial compensations such as salary, allowances, fringe reimbursement in occasionally basis and special occasion and work security received from the firm. According to Tax Brown and Chandrashekaran (1998) based on respondents working in telecommunications, insurance, banking and emergency service providers about the handling of complaints found that the distributive justice value might be improved or compromised by interactional and procedural justice.

Distributive justice is about compensation given to unhappy customers towards solving or reducing the problems (Mattila, 2001). The compensation can be in the form of discounts, free of charge, tokens, free upgrading and 
additional services, replacement of product and apologies from mobile network providers with the goal to improve the satisfaction level of mobile users through service recovery attempt. Distributive justice emphasized on the perceived justice assessment by clients during poor service delivery towards the solution offered by service providers (Blodget, Hill, \& Tax, 1997). Therefore the levels of compensation given to customers are different and depend on the degree of service failure. For example a customer that are very angry and frustrated might receive a reasonable fix for the poor service delivery, while a customer that feels treated poorly due to poor service delivery might receive some added value of apology (Boshoff, 1997). In Sparks and McColl-Kennedy (2001) studied revealed that in USA restaurant the clients are very happy when 50 percent reimbursement was given as a payment for the poor delivery of service. Therefore compensation, refund or discount given by service providers to compensate the poor service delivery may help the mobile phone users feel grateful to change their satisfaction level.

\subsection{Procedural Justice}

Procedural justice procedures verify the process taken for final result achievement (Greenberg, 1990). It is a decision making procedure used to achieve the end results (Brown \& Chandrashekaran, 1998). Procedural justice relates to an approach or a procedure that organization use toward making a decision (Organ, 1988). Attention to equality procedures are important to people. The theory of procedure justice mentions as a process undertaken to achieve results; the essential regulations, suitable guidelines and methods need to be selected by the mobile network company. The equality methods should be unbiased, reliable, correct information, ethical and indeed about the importance of all parties involved (Leventhal, 1976, 1980). In the field of method solving conflicts, Thibaut and Walker (1978) describe that when control over regulations for decisions had by individual, easier for them to accept the results, even if it be bad for them. Quick to respond and flexibility of provider is important and correlated with user satisfaction (Bitner et al., 1990; Parasuraman et al., 1985). The equality process that is used will establish type of outcome, outcomes beneficiary and technique used for distribution of outcomes. Cropanzano and Stein, (2009) cited in (Yaghoubi, Salarzehi, Moloudi, \& Yaghoubi, 2010).

The policy of response speed, accessibility, flexibility and time taken to provide information to the customer is considered to be the evaluation of justice procedures carried out by the organization. The objective is to turn out the unhappy customers to happy customers (Loi, Hang, \& Foley, 2006; Cengiz, Er, \& Kurtaran, 2007). One of the dimensions of justice procedure was used in the study of recovery service is the timely response (Boshoff, 1997; McColl-Kennedy Sparks, 2003). The other dimensions used for procedural justice research are flexibility, responsiveness, effectiveness, access control and decisions (Clemmer, 1993; Tax et al., 1998). In procedural justice study, it is essential due to mobile users are likely to be happy with the other perceived justice dimensions such as distribution and interaction but can still be frustrated with the rules and procedures of the mobile network companies to achieve satisfaction of clients with recovery of services (Kelley, Hoffman, \& Davies, 1993).

\subsection{Interactional Justice}

Interactional justice is about dealing of interpersonal actions in terms of verbal communication or non-verbal cues in performing the guidelines and delivery of result (Tax et al., 1998). Therefore it is associated with the techniques of how the practice of recovery process service is being carried out and how the recovery results are demonstrated (Hoffman \& Kelly, 2000). The components of interactional justice including clarification of the poor delivery of service or product, courtesy, honesty, attempt to solve the problem and empathy (Blodgett, Hill, \& Tax, 1997; Tax et al., 1998). The study carried out in sectors such as airlines, health service, restaurant and automobiles repair concluded that procedure and interaction justice appears to improve justice and happiness perception when the client has been offered by distribute awards after the failure of the service (Goodwin \& Ross, 1992). In a study done by Blodgett et al. (1997) over dissatisfaction with a pair of jogging shoes being used is found that procedural justice explaining less significant difference compared to interactional and distribute justice regarding the intention of the repurchase by client or intention on negative word-of-mouth spread. Price, Arnould and Tierney (1995) suggested that intimate proxemics increase the participation and bonding of emotions and relations will widen an open transaction boundary. The transaction has been explained as the gathering of friends (Mars \& Nicod, 1984). This will linked with the confidence whereby mobile network companies are concerned that they are very important person. Thus, the gathering that takes the emotion of the link as different business and link of the product service become more vital compare to focus aspects (Siehl, Bowen, \& Pearson, 1992).

A service failure is referred to service performance of service provider that drops below the client's expectation (Hoffman \& Bateson, 1997). When failure of service occurs, client expectation is to link with service providers that can quickly take action to solve the problems. Failures of services provide chance for information to the 
approachable for making of decision, relatively than recovery itself, which permits the clients to carry on to value the bond. The methods for interactional justice assessment are related to the satisfaction of clients are polite, clarification, equality, empathy and making apologies (Tax et al., 1998; Goodwin \& Ross, 1992). The mobile phone customers will demonstrate negative feelings in case that not much attention given by service providers related to interactional justice while trying to recover the services by service providers.

Perceived justice that affects assessment of individual on exchange has three dimensions. The dimensions are distributive, procedural and interactional justices. Tax and Brown (2000) suggests that if firms do badly even to one of the dimensions of justice the possible for satisfaction of client with the overall of recovery service efforts also will be badly affected. Studies related to service recovery show that the overall satisfaction of client with service recovery improved significantly when there is a positive view of perceptions regarding perceived justice (Tax \& Brown, 2000; Sparks \& McColl-Kennedy, 2001; Mattila \& Mount, 2003; Yi, Cheng, \& Wei, 2010; Bradley \& Sparks, 2012). The recovery strategies justice namely procedural, interactional and distributive were found significantly influenced the retention of clients in the Malaysian banking sector (Kamal, 2009). Distributive fairness and procedural fairness significantly affected re patronage behavior intention while interactional fairness was not supported in health care industries in Taiwan (Tai, Chiu, Chwen, \& Hsing, 2008). In retail business the actions by organizations on service recovery improve perceived justice when the organizations is handling equally with the poor service delivery and this will change customer attitudes towards the organization (Hong, Ju, \& Chien, 2008). According to Davoud Ishak, Malliga, Hamed (2012) procedural justices had stronger effect on switching intentions among mobile phones used in Malaysia compare to distributive and informational justices. While Cho, Im and Hiltz (2003) found that the complaints component specifically fall into three dimensions of justice. The three justice elements have direct links with happiness of clients, word of mouth and intention to buy again of service recovery via email (Neale \& Murphy, 2007). In other studies there are positive affect of distributive and procedural justice towards employee fulfillment and performance, enhance firm commitment and in reducing employee leaving the organization (Loi, Hang-Yue, \& Foley, 2006; Suliman, 2007; Hossam, 2010; Abdallah, 2012). Procedural and interactional justice is linked positively with organizational commitment (affective and continuance commitment) and job performance of employees working at state owned organizations (Abubakr \& Majid, 2013). Yang and Zhang (2012) have categorized distributive, procedural and interactive justice as organizational justice and had found a positive influence on perceived organizational support towards professional managers in manufacturing and service industry in China. In another studied by Palaiologos, Papazekos \& Panayotopoulou (2011) also have used organizational justice has main factor and found that it effect different element of performance appraisal and most important is satisfaction element. Recently Nancy (2011) found that only distribute justice have significant influence on pay satisfaction of employees in public university while procedural, interpersonal, information justice are not related. In other hand $\mathrm{Yi}$, Shun, Hsin, \& Yu(2011) research in e tailing business in Taiwan the distribute, procedural and interactive justice have been categorized as service recovery justice found that only interactional justice can moderate the inverse link between severity of service failure and loyalties of clients. Therefore, it is expected that the three dimensions of justice that have been discussed above, each will contribute to the assessment of recovery and also combine to describe the value of a high proportion difference in overall fulfillment with the evaluation of the customer from recovery of service attempts (Smith \& Bolton, 1998; Tax \& Brown, 2000).

\section{Methodology}

In this study, by using Structural equation modeling (SEM), confirmatory factor analysis (CFA) and hypotheses are examined in the similar analysis. In addition, SEM method offer comprehensive information about the degree to which study model is supported by the data compared to the using of regression techniques. Based on Sentosa, Ming, Soebyakto, and Nik Mat (2012) have recommended that SEM is able to perform the analysis through the techniques of statistics namely covariance analysis which is engaged in AMOS package version 20.0. This study involved individuals that subscribe to the service of mobile phone with any service provider in the Central Region of Malaysia. Data obtained from 310 respondents has been coded and stored in SPSS version 20. AMOS version 20 was used to analyze the data. In the process of screening data for outliers, 30 data set has been removed because Mahalanobis (D2) values above the $\chi^{2}$ values $(\chi 2=63,87 ; \mathrm{n}=33, \mathrm{p}<.001)$. Finally 280 sets of data left to be used for further analysis. The purpose of the initial evaluation is to check the fit of the constructs observed to the latent constructs (also referred to as model of measurement). The second evaluation process in SEM analysis is a model measurement analysis for evaluating the convergent and discriminant validity, composite reliability model of the hypothesis. 


\section{Findings}

A CFA and full model measurement structure of uni and multi-dimensional measures have been carried out. The aim is too examined whether the justice is measured as uni-dimensional or multi-dimensional. Figure 1 and 2 illustrated graphical presentation of confirmatory factor analysis, whereas Figure 3 and 4 illustrated the graphical presentation for the measurement model result.

The uni-dimensional measurement model value for GFI was 0.833 that is below suggested value $\geq 0.90$, TLI was 0.936 and CFI value was 0.947 which is above recommended value of $\geq 0.90$, for AGFI was 0.758 and is below suggested value of $\geq 0.80$, for RMSEA was 0.118 and the value was not between suggested value $\leq 0.08$. Hence the findings indicate for uni-dimensional model the TLI and CFI only meet measures of fit. The value of $\chi^{2} / \mathrm{df}$ (2.827) for uni-dimensional is higher than the value of $\chi^{2} / \mathrm{df}(1.849)$ multi-dimensional model. This value is slightly below than $\leq 3$ as suggested value. The multi measurement model value for GFI was 0.90 , TLI was 0.97 and CFI value was 0.977 which is above recommended value of $\geq 0.90$, for AGFI was 0.847 and is above suggested value of $\geq 0.80$, for RMSEA was 0.08 and the value was between suggested value $\leq 0.08$. Hence, all the multi-dimensional measurement has met all the criteria of recommended values. The value of $\chi^{2} / \mathrm{df}$ is below 2. This shows the model is much better compared to the earlier model. Based on the result, it is concluded that fits of data for multi-dimensional measure is better compared to the measurement of uni-dimensional.

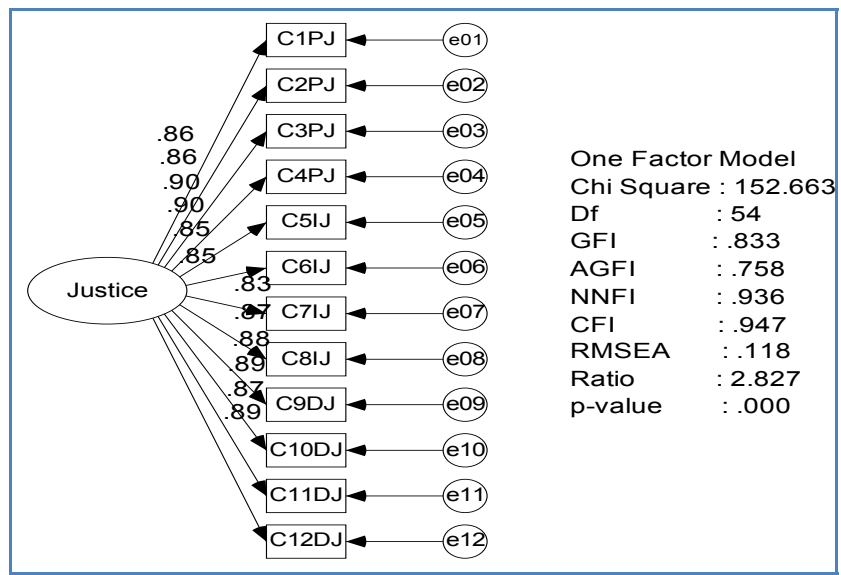

Figure 1. Result of confirmatory factor analysis for the uni-dimensional measurement

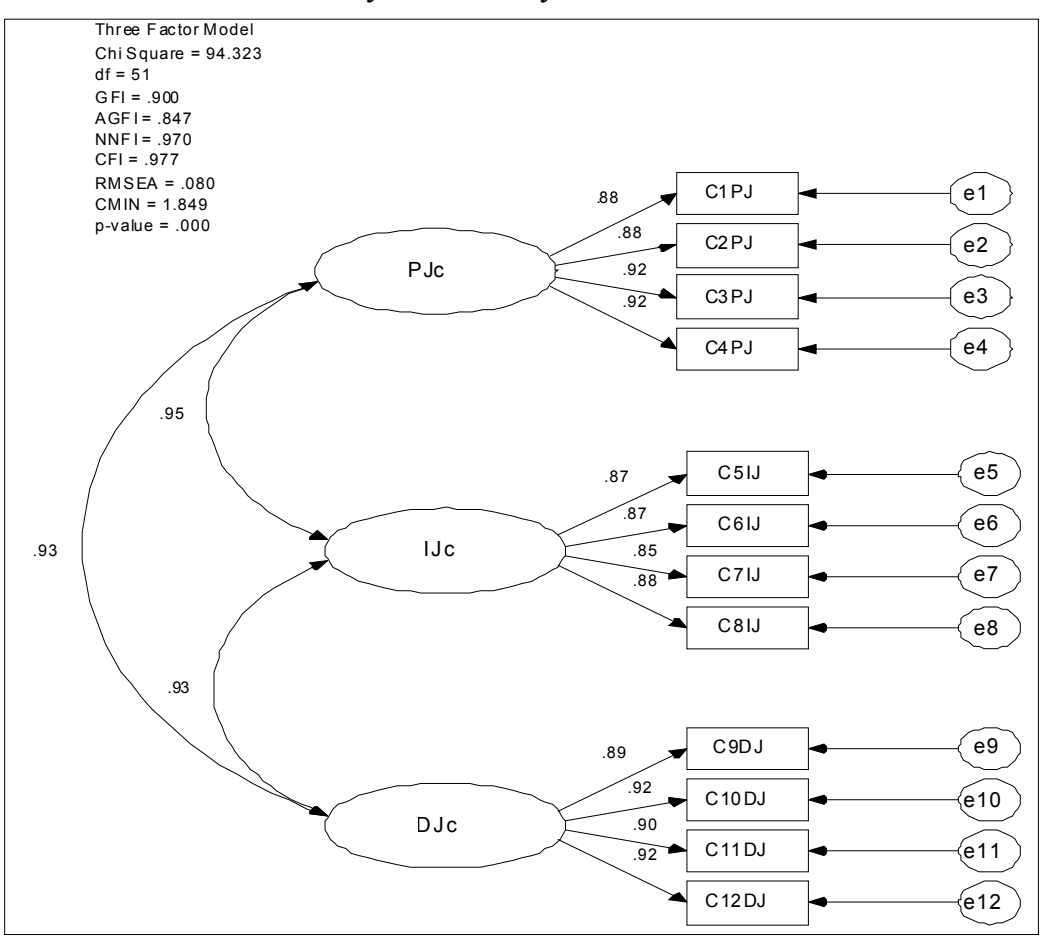

Figure 2. Result of confirmatory factor analysis for the multi-dimensional measurement 
In a subsequent analysis, the service recovery constructs was incorporated in the full model measurement. This was done based on previous studies that recommended there is a direct correlation among perceived justice and recovery of service satisfaction. The uni-dimensional measurement model value for GFI was 0.830 that is below suggested value $\geq 0.90$, TLI was 0.948 and CFI value was 0.956 which is above recommended value of $\geq 0.90$, for AGFI was 0.771 and is below suggested value of $\geq 0.80$, for RMSEA was 0.097 and the value was not between suggested value $\leq 0.08$. The result showed that uni-dimensional model only meets TLI and CFI measures of fit. The value of $\chi 2 / \mathrm{df}(199.99)$ is above the value of $\chi 2 / \mathrm{df}(140.72)$ for multi-dimensional model. The result was slightly below than $\leq 3$ as suggested value. The multi measurement model value for GFI was 0.879 which is below suggested value of $\geq 0.90$, TLI was 0.972 and CFI value was 0.977 which is above recommended value of $\geq 0.90$, for AGFI was 0.827 and is above suggested value of $\geq 0.80$ and for RMSEA was 0.072 and the value was between suggested value $\leq 0.08$. Therefore multi-dimensional measure results show that TLI, CFI, AGFI, RMSEA was met the recommend values. The value of $\chi 2 / \mathrm{df}$ is less than 2 . This indicated the model is much better compared to the earlier model. Based on the result, it is concluded that the fits of data for multi-dimensional is better compared to uni-dimensional measure.

All observed items factor loadings for final measurement model analysis are adequate ranging from 0.86 to 0.94 . The results are above the recommended limit of 0.5 for factor loadings (Hair, Black, Babin, \& Anderson, 2010). The values indicate that every variable accepted with the convergent validity assessment. The remained items for the procedural justice variables are with three items, interactional justice variable are with four items, distributive justice variable are with four items and customer satisfaction variable are with three items.

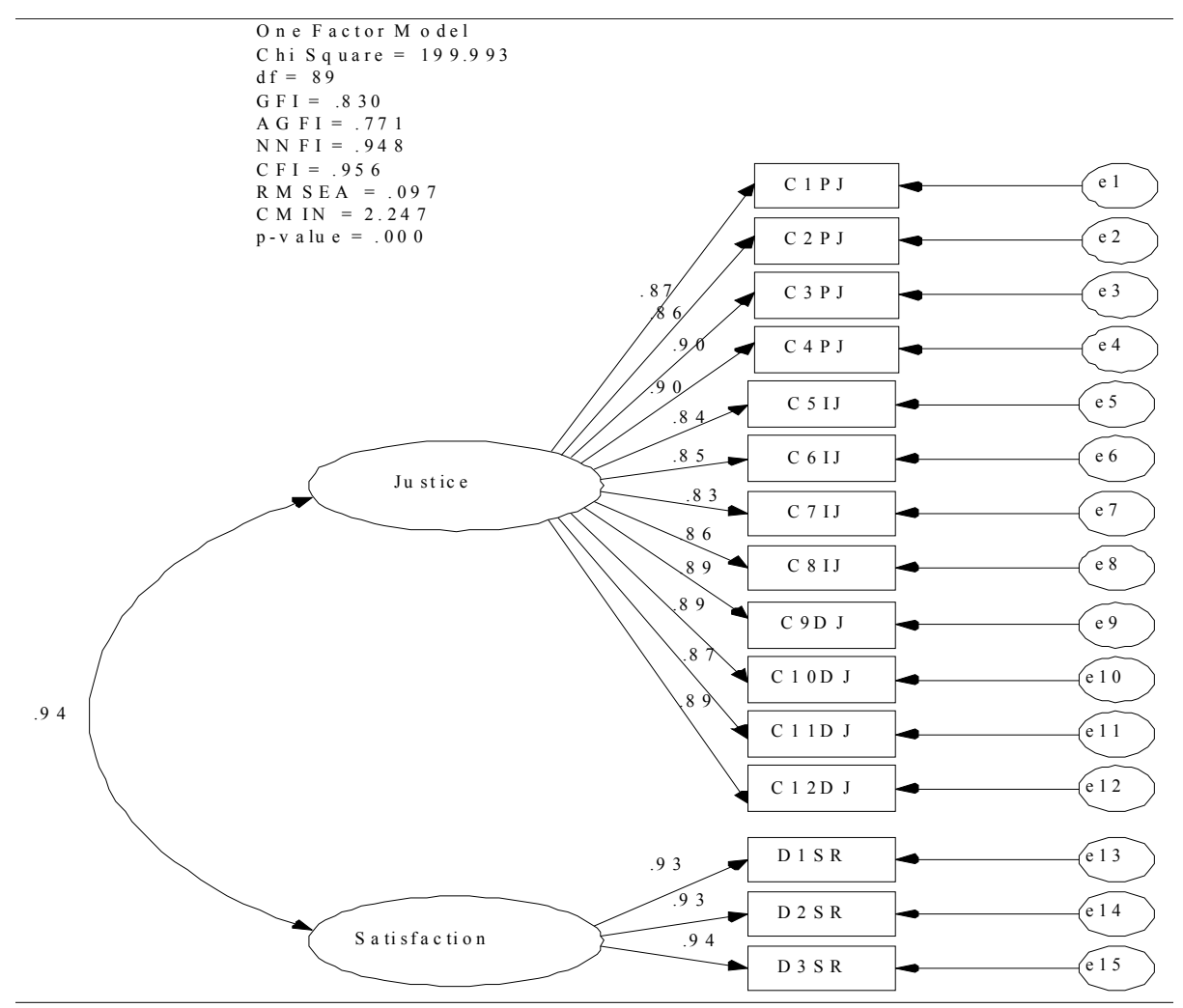

Figure 3. Uni-dimensional measurement model

\subsection{Discriminant Validity of Constructs}

The multi-dimensional model measurement with the average variance extracted (AVE), composite reliability (CR) and loadings exhibited in table 1. According to Fornell and Larcker, (1981) to support the discriminant validity, the square root of the average variance extracted (AVE) must be above the correlation squared of the other variables. The result from this study showed that the square root of the AVE values is above the correlation squared. Hence, it supported the discriminant validity (Sentosa et al., 2012). 


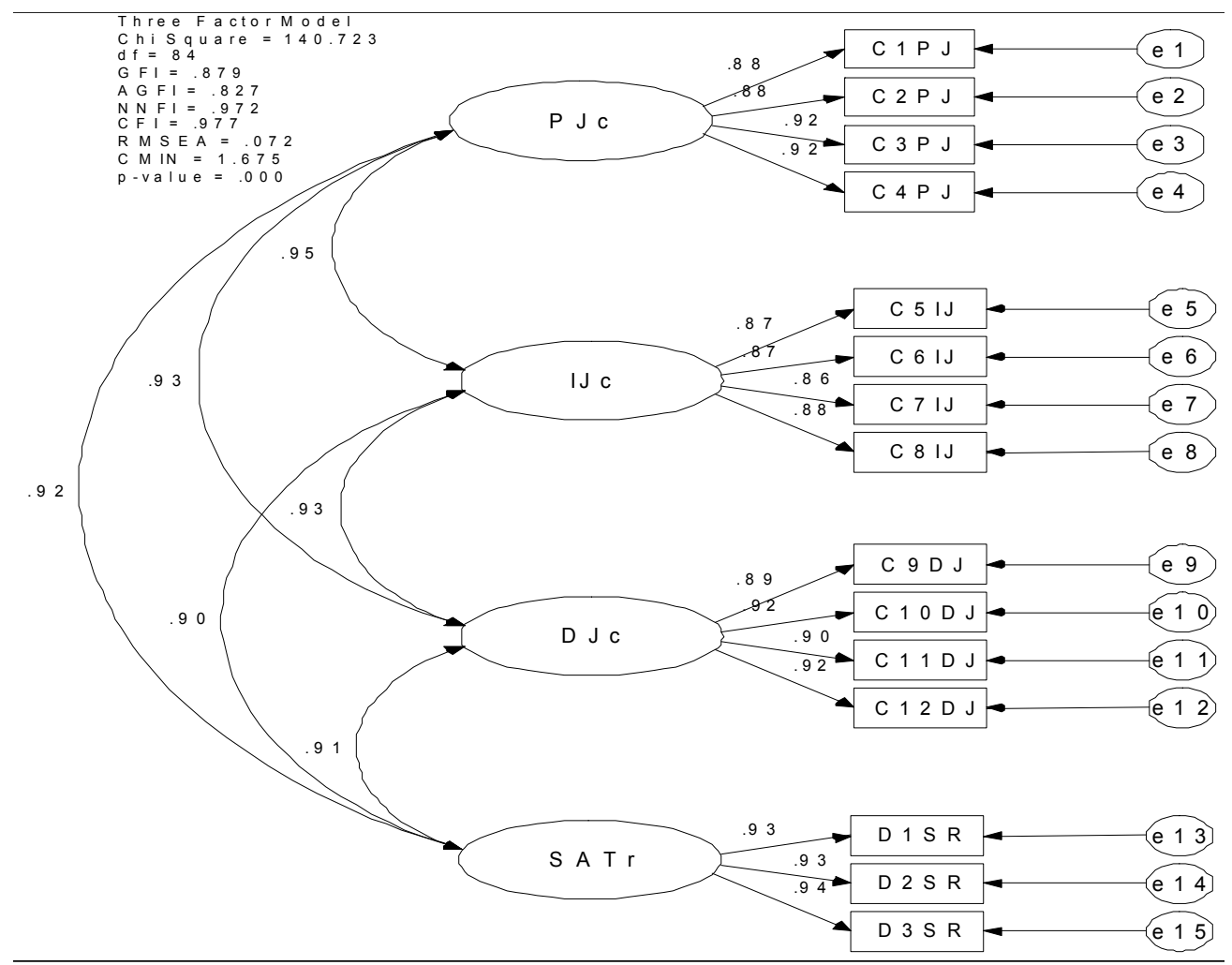

Figure 4. Multi-dimensional measurement

Table 1. Result of measurement model

\begin{tabular}{lllll}
\hline Model Construct & Measurement Item & Std. Regressions Weight & CR & AVE \\
\hline Procedural Justice & C1PJ & 0.88 & 0.945 & 0.810 \\
& C2PJ & 0.88 & & \\
C3PJ & 0.92 & & \\
Interactional Justice & C4PJ & 0.92 & 0.926 & 0.757 \\
& C5IJ & 0.87 & & \\
& C6IJ & 0.87 & & \\
Distributive Justice & C7IJ & 0.86 & & \\
& C8IJ & 0.88 & & \\
& C9DJ & 0.89 & & \\
& C10DJ & 0.92 & & \\
& C11DJ & 0.90 & & \\
Customer Satisfaction & C12DJ & 0.92 & & \\
& D1SR & 0.93 & & \\
& D2SR & 0.93 & & \\
\hline
\end{tabular}

Table 2. Result of construct discriminant validity

\begin{tabular}{lllll}
\hline Variable & $\begin{array}{l}\text { Procedural } \\
\text { Justice }\end{array}$ & $\begin{array}{l}\text { Interactional } \\
\text { Justice }\end{array}$ & $\begin{array}{l}\text { Distributive } \\
\text { Justice }\end{array}$ & $\begin{array}{l}\text { Satisfaction with Service } \\
\text { recovery }\end{array}$ \\
\hline Procedural Justice & $\mathbf{0 . 9 0 0}$ & & & \\
Interactional Justice & 0.903 & $\mathbf{0 . 8 7 0}$ & & \\
Distributive Justice & 0.865 & 0.865 & $\mathbf{0 . 9 0 8}$ & \\
Satisfaction with Service Recovery & 0.846 & 0.810 & 0.828 & $\mathbf{0 . 9 3 3}$ \\
\hline
\end{tabular}




\section{Discussions and Conclusions}

All CFAs of variables showed good results such as the goodness of fit index CMIN ratio/df $(<2)$; p-value ( $>$ 0.05 ); Good Fit Index (GFI) of $>$. 95; and the root mean squared error estimation (RMSEA) value of less than. $08(<.08)$ as depicted in Figure 1 and 2. Based on the GFI, CFI, TLI, RMSEA criteria evaluation, the measurement model in this study have fit well with data $(\mathrm{Yi}, 1988)$. The findings from this study validated that justice as multi-dimensions to three dimensions, namely procedures, interaction and distribution. Therefore, it is proposed to integrate the three dimensions of justice as perceived justice in the policies of the organization as established from previous findings. This will provide chance to the researchers to improve the model by incorporating the policy of the organization that is linked with justice procedures namely process control, responsiveness, effectiveness, access control and decisions, and flexible. (Tax, Brown, \& Chandrashekaran, 1998), interactional justice for instance clarification or causal account, polite, equality, attempts and kindness (Tax, Brown, \& Chandrashekaran, 1998) and distributive justice for example reimbursement in the variety of price reduction, free of charge, tokens, free upgrading and additional services, replacement of product and request for forgiveness (Blodgett, Hill, \& Tax, 1997; Hoffman \& Kelley, 2000).

\section{Limitations}

As with any research undertaking, this research also have a range of limitations that confine the generalization of the result and open ways for further study. Firstly, from a methodological standpoint, 310 respondents were used in this study and issues such as location and representativeness of the sample may have affected the findings. Broader sample of respondent that subscribe to the service of mobile phone can be employed that may give a more inclusive result.

Secondly, related to the data collected from respondent which depends on their honesty and remembrance particularly for customer complains part. It is recognized that individuals would agree more in answering for socially desirable questions compare to expressing their feelings and opinions fully and truly. The third limitation refers to the sample of respondents are taken from one industry and the study area was undertaken in Central Region of Malaysia.

Furthermore how to assured and improve trust about particular recovery to the potential clients, example: customer personal data were not sold to others can be added for future studies (George, 2002).

\section{Future Research Suggestions}

Despite interesting findings and limitations found in this research and limitations; it is essential to identify the requirement for further study. The findings from this study may provide the basis for the service provider to formulate appropriate strategies to ensure customers continue to be loyal to them. In addition the service providers also need to identify the reason for non-complainants are not complaining.

Upcoming studies should examine this model in various service sectors such as health, lodging, restaurant, financing and educational industries. Furthermore how to assured and improve trust about particular recovery to the potential clients, example: customer personal data were not sold to others can be added for future studies (George, 2002). In addition, refining the measures used in this study and employs in a study, particularly to investigate justice and its antecedents would be interesting for upcoming research.

Continued study is required to enhance this research and to deal with the limitation of current research. As such, it is expected that this research will provide an initial overview and understanding of the severity of service failures and service recovery satisfaction effects towards client satisfaction for mobile phone users in the telecommunications industry in the Malaysian context.

\section{References}

Adams, J. S. (1963). Toward an understanding of inequity. Journal of Abnormal and Social Psychology, 67, 422-436. http://dx.doi.org/10.1037/h0040968

Adams, J. S. (1965). Inequity in social exchange. In L. Berkowitz (Ed.), Advances in Experimental Social Psychology (pp. 267-299). Academic Press, New York, NY.

Andreassen, T. W. (1999). What drives customer loyalty with complaint resolution? Journal of Service Research, 2, 324-332. http://dx.doi.org/10.1177/109467059914004

Berry, L. L., \& Parasuraman, A. (1991). Marketing services: Competing through quality. New York: The Free Press.

Blodgett, J. G., Hill, D. J., \& Tax, S. S. (1997). The effects of distributive, procedural and interactional justice on 
post complaint behavior. Journal of Retailing, 73, 185-210. http://dx.doi.org/10.1016/S0022-4359(97) 90003-8

Boshoff, C. (1997). An Experimental Study of Service Recovery Options. International Journal of Service Industry Management, 8(2), 110-130. http://dx.doi.org/10.1108/09564239710166245

Bradley, G., \& Sparks, B. (2012). Explanations: If, when, and how they aid service recovery. Journal of Services Marketing, 26(1), 41-51. http://dx.doi.org/10.1108/08876041211199715

Cengiz, E., Er, B., \& Kurtaran, A. (2007). The effects of failure recovery strategies on customer behaviours via complainants' perceptions of justice dimensions in banks. Banks and Banks Systems, 2(3), 173-196.

Chebat, J. C., \& Slusarczyk, W. (2005). How emotions mediate the effects of perceived justice on loyalty in service recovery situations: An empirical study. Journal of Business Research, 58(5), 664-673. http://dx.doi. org/10.1016/j.jbusres.2003.09.005

Cho, Y., Im, I., \& Hiltz, R. (2003). The impact of e-services failures and customer complaints on electronic commerce customer relationship management. Journal of Consumer Satisfaction, Dissatisfaction and Complaining Behavior, 16, 106-118.

Clemmer, J. (1993). Making change work: Integrating, focus, effort and direction. Canadian Business Review, 20(4), 29-31.

Colquitt, J. (2001). On the dimensionality of organizational justice. A construct validation of a measure. Journal of Applied Psychology, 86, 386-400. http://dx.doi.org/10.1037/0021-9010.86.3.386

Colquitt, J., Conlon, D., Wesson, M., Porter, C., \& Ng, Y. (2001). Justice at the millennium. A meta-analytic review of 25 years of organizational justice research. Journal of Applied Psychology, 86, 425-445. http://dx.doi.org/10.1037/0021-9010.86.3.425

Cropanzano, R., \& Stein, J. H. (2009). Organizational Justice and Behavioral Ethics: Promises \& Prospects. Business Ethics Quarterly, 19, 193-233. http://dx.doi.org/10.5840/beq200919211

Deutsch, M. (1975). Equity, equality, and need: What determines which value will be used as the basis of distributive justice. Journal of Social Issue, 31, 137-149. http://dx.doi.org/10.1111/j.1540-4560.1975. tb01000. $x$

Dick, A. S., \& Basu, K. (1994). Consumer loyalty: Toward an integrated conceptual Framework. Journal of Academy Marketing Science, 22(2), 99-113. http://dx.doi.org/10.1177/0092070394222001

Elamin, A. M. (2012). Perceived organizational justice and work-related attitudes: A study of Saudi employees. World Journal of Entrepreneurship, Management and Sustainable Development, 8(1), 71-88. http://dx.doi. org/10.1108/20425961211221633

Elanain, H. M. A. (2010). Testing the direct and indirect relationship between organizational justice and work outcomes in a non-Western context of the UAE. Journal of Management Development, 29(1), 5-27. http://dx.doi.org/10.1108/02621711011009045

Folger, R. (1987). Reformulating the preconditions of resentment. A referent cognitions model. In J. Masters, \& W. Smith (Eds.), Social Comparison, Social Justice and Relative Deprivation: Theoretical, Empirical and Policy Perspectives (pp. 183-215). Lawrence Erlbaum Associates, Hillsdale, NJ.

Folger, R. (1993). Reactions to mistreatment in work. In J. K. Murnighan (Ed.), Social Psychology in Organizations (pp. 161-183). Advances in Theory and Research, Prentice-Hall, Englewood Cliffs, NJ.

Goodwin, C., \& Ross, I. (1992). Consumer responses to service failures. Influence of procedural and interactional fairness perceptions. Journal of Business Research, 25, 149-153. http://dx.doi.org/10.1016/0 148-2963(92)90014-3

Greenberg, J. (1990). Organizational justice, yesterday, today and tomorrow. Journal of Management, 16, 399-432. http://dx.doi.org/10.1177/014920639001600208

Greenberg, J. (2001). Studying organizational justice cross-culturally: Fundamental challenges. The International Journal of Conflict Management, 12, 365-375. http://dx.doi.org/10.1108/eb022864

Hair, J. F., Black, W. C., Babin, B. J., \& Anderson, R. E. (2010). Multivariate Data Analysis. Upper Saddle River, NJ: Prentice-Hall.

Har, C. W. L., Heskett, J. L., \& Sasser, E. W. Jr. (1990). The profitable art of service recovery. Harvard Business Review, 68, 148-156. 
Hocutt, M. A., Bowers, M. R., \& Donavan, D. T. (2006). The art of service recovery: Fact or fiction? Journal of Services Marketing, 20(3), 199. http://dx.doi.org/10.1108/08876040610665652

Hoffman, K. D., \& Bateson, J. E. G. (1997). Essentials of Services Marketing. Fort Worth, TX: Dryden.

Hoffman, K. D., \& Kelley, S. W. (2000). Perceived justice needs and recovery evaluation: A contingency approach. European Journal of Marketing, 418-432. http://dx.doi.org/10.1108/03090560010311939

Hong, S. C., Ju, C. L., \& Chien, M. T. (2008). The influence of service recovery on perceived justice under different involvement level an evidence of retail industry Contemporary Management Research, 4(1), 57-82.

Hunt, H. K., Hunt, D., \& Hunt, C. T. (1988). Consumer grudge holding. Journal of Consumer Satisfaction, Dissatisfaction and Complaining Behaviour, 1, 116-118.

Kau, A. K., \& Loh, W. Y. (2006). The effects of service recovery on consumer satisfaction: A comparison between complaints and non-complainants. Journal of Services Marketing, 20(2), 101-111. http://dx.doi. org $/ 10.1108 / 08876040610657039$

Keaveney, S. M. (1995). Customer switching behavior in service industries: An exploratory study. Journal of Marketing, 59(4), 71-82. http://dx.doi.org/10.2307/1252074

Kelley, S. W., Hoffman, K. D., \& Davis, M. A. (1993). A typology of retail failures and recoveries. Journal of Retailing, 69(4), 429-452. http://dx.doi.org/10.1016/0022-4359(93)90016-C

Leventhal, G. S. (1976). The distribution of rewards and resources in groups and organizations. In L. Berkowitz, \& E. Walster (Eds.), Equity Theory (pp. 92-131). Toward a General Theory of Social Interaction, Academic Press, New York, NY.

Leventhal, G. S. (1980). What should be done with equity theory? New approaches to the study of fariness in social relationships. In K. J. Gergen, M. S. Greenberg, \& R. H. Willis (Eds.), Social Exchange: Advances in Theory and Research (pp. 27-55). New York, NY: Plenum Press. http://dx.doi.org/10.1007/978-1-46133087-5_2

Levesque, T. J., \& McDougall, G. H. G. (1993). Managing customer satisfaction: The nature of service problems and customer exit, voice and loyalty. Asia Pacific Journal of Quality Management, 2(2), 40-58.

Loi, R., Hang-Yue, N., \& Foley, S. (2006). Linking employees' justice perceptions to organizational commitment and intention to leave: The mediating role of perceived organizational support. Journal of Occupational and Organizational Psychology, 79, 101-120. http://dx.doi.org/10.1348/096317905X39657

Lovelock, C. H. (1996). Services Marketing (3rd ed.). Prentice-Hall, Upper Saddle River, NJ.

Lovelock, C., Wirtz, J., \& Keh, H. T. (2002). Services Marketing in Asia, Managing People, Technology and Strategy (p. 231). Prentice Hall International Incorporation, Singapore.

Mars, G., \& Nicod, T. (1984). The World of Waiters. George Allen \& Unwin, London.

Mattila, A. S. (2001). The effectiveness of service recovery in a multi-industry setting. Journal of Services Marketing, 15(7), 583-596. http://dx.doi.org/10.1108/08876040110407509

Mattila, A. S., \& Cranage, D. (2005). The impact of choice on fairness in the context of service recovery. Journal of Services Marketing, 271-279.

Mattila, A. S., \& Mount, D. J. (2003). The role of call centers in mollifying disgruntled guests. Cornell Hotel and Restaurant Administration Quarterly, 44(4), 75-80. http://dx.doi.org/10.1016/S0010-8804(03)90260-6

Maxham, J. G. I., \& Netemeyer, R. G. (2002). A Longitudinal Study of Complaining Customers' Evaluations of Multiple Service Failures and Recovery Efforts. Journal of Marketing, 66(4), 57-71. http://dx.doi.org/10. 1509/jmkg.66.4.57.18512

McColl-Kennedy, J. R., \& Sparks, B. A. (2003). Application of fairness theory to service failures and service recovery. Journal of Service Research, 5(3), 251-266. http://dx.doi.org/10.1177/1094670502238918

McCollough, M. A. (2000). The effect of perceived justice and attribution regarding service failure and recovery on post-recovery customer satisfaction and service quality attributes. Journal of Hospitality \& Tourism Research, 24(4), 423-447. http://dx.doi.org/10.1177/109634800002400402

Michel, S. (2001). Analyzing service failures and recoveries: A process approach. International Journal of Service Industry Management, 12(1), 20-33. http://dx.doi.org/10.1108/09564230110382754

Moorman, N. (1993). Justice as a mediator of the relationship between methods of mentoring and organizational 
citizenship behavior. Academy of Management Journal, 36, 527-555. http://dx.doi.org/10.2307/256591

Nancy, E. D. (2011). Perceived pay communication, justice and pay satisfaction. Employee Relations, 33(5).

Neala, L., \& Murphy, J. (2007). Perceived Justice and Email Service Recovery. Australasian Marketing Journal, $15(3), 5-20$.

Nikbin, D., Ismail, I., Marimuthu, M., \& Armesh, H. (2012). Perceived justice in service recovery and switching intention: Evidence from Malaysian mobile telecommunication industry. Management Research Review, 35(3/4), 309-325. http://dx.doi.org/10.1108/01409171211210181

Oliver, R. L. (1980). A Cognitive Model of the Antecedents and Consequences of Satisfaction Decisions. Journal of Marketing Research, 17, 460-469. http://dx.doi.org/10.2307/3150499

Oliver, R. L., \& Swan, J. E. (1989). Consumer perspective of interpersonal equity and satisfaction in transactions: A field survey approach. Journal of Marketing, 53, 21-35. http://dx.doi.org/10.2307/1251411

Palaiologos, A., Papazekos, P., \& Panayotopoulou, L. (2011). The Effect of Human Resource Management Practices on Job Involvement in Selected Private Companies in Jordan. Journal of European Industrial Training, 35(8).

Parasuraman, A., Zeithaml, V. A., \& Berry, L. L. (1985). A conceptual model of service quality and its implications for future research. Journal of Marketing, 49, 41-50. http://dx.doi.org/10.2307/1251430

Price, L. L., Arnould, E. J., \& Tierney, P. (1995). Going to extremes: Managing service encounters and assessing provider performance. Journal of Marketing, 9, 83-97. http://dx.doi.org/10.2307/1252075

Santos, C. P., \& Fernandes, D. V. (2008). Antecedents and Consequences of Consumer Trust in the Context of Service Recovery. Brazilian Administration review, 225-244. http://dx.doi.org/10.1590/S1807-7692200 8000300005

Sentosa, I., Ming, W. C., Soebyakto, B. B., \& Nik Mat, N. K. (2012). A Structural Equation Modeling of Internet Banking Usage in Malaysia. Journal of Arts, Science and Commerce, 3(1), 75-86.

Siehl, C., Bowen, D. E., \& Pearson, C. M. (1992). Service encounters as rites of integration: An information processing model. Organization Science, 3, 537-555. http://dx.doi.org/10.1287/orsc.3.4.537

Sindhav, B., Holland, J., Rodie, A. R., Adidam, P. T., \& Pol, L. G. (2006). The Impact of Perceived Fairness on Satisfaction: Are Airport Security Measures Fair, Does it Matter? Journal of Marketing Theory and Practice, 323.

Smith, A. K., \& Bolton, R. (1998). An experimental investigation of customer reactions to service failure and recovery encounters. Journal of Service Research, 1, 65-81. http://dx.doi.org/10.1177/1094670598 00100106

Smith, A. K., Bolton, R. N., \& Wagner, J. (1999). A model of customer satisfaction with service encounters involving failure and recovery. Journal of Marketing Research, 36, 356-372. http://dx.doi.org/10.2307/31 52082

Sparks, B. A., \& McColl-Kennedy, J. R. (2001). Justice strategy options for increased customer satisfaction in a services recovery setting. Journal of Business Research, 54(12), 209-218. http://dx.doi.org/10.1016/S0148 $-2963(00) 00120-X$

Suliman, A. M. T. (2007). Links between justice, satisfaction and performance in the workplace: A survey in the UAE and Arabic context. Journal of Management Development, 26(4), 294-311. http://dx.doi.org/10.1108 /02621710710740075

Suliman, A., \& Kathairi, M. A. (2013). Organizational justice, commitment and performance in developing countries: The case of the UAE. Employee Relations, 35(1), 98-115. http://dx.doi.org/10.1108/01425451311 279438

Swanson, S. R., \& Kelley, S. W. (2001). Service recovery attributions and word-of-mouth intentions. European Journal of Marketing, 35(1), 194-211. http://dx.doi.org/10.1108/03090560110363463

Tai, K. Y., Chiu, Y. T., Chwen, T. S., \& Hsing, Y. H. (2008). The impact of service recovery on re patronage behavioral intentions: A case of the health center. International Conference on Business and Information, July 7-9, 2008, Seoul, Korea.

Tam, S. (2013, February 6). Complaints against Telco providers doubled: Consumer group. Yahoo Newsroom. Retrieved from http://my.news.yahoo.com 
Tax, S. S., \& Brown, S. W. (2000). Service recovery: Research insights and practices. In T. A. Swartz, \& D. Iacobucci (Eds.), Handbook of Services Marketing and Management (pp. 271-285). Sage Publication, Thousand Oaks, CA. http://dx.doi.org/10.4135/9781452231327.n19

Tax, S. S., Brown, S. W., \& Chandrashekaran, M. (1998). Customer evaluations of service complaint experiences: Implications for relationship marketing. Journal of Marketing, 62, 60-76. http://dx.doi.org/10.2307/ 1252161

Thibault, J., \& Walker, L. (1975). Procedural Justice. A Psychological Analysis, Erlbaum, Hillsdale, NJ.

Thibaut, J., \& Walker, L. (1978). A theory of procedure. California Law Review, 66, 541-566. http://dx.doi.org $/ 10.2307 / 3480099$

Ting, D. H. (2004). Service quality and satisfaction perceptions: Curvilinear and interaction effect. International Journal of Bank Marketing, 22(6), 407-420. http://dx.doi.org/10.1108/02652320410559330

Weun, S., Beatty, S. E., \& Jones, M. A. (2004). The impact of service failure severity on service recovery evaluations and post-recovery. Journal of Services Marketing, 18(2), 133-146. http://dx.doi.org/10.1108/ 08876040410528737

Yaghoubi, N. M., Salarzehi, H., Moloudi, J., \& Yaghoubi, E. (2010). Review of Relationship between Intellectual Capital and Organizational Justice. Asian Social Science, 120-126.

Yang, F., \& Zhang, L. (2012). Organizational justice and perceived organizational support: The moderating role of conscientiousness in China. Nankai Business Review International, 3(2), 145-166. http://dx.doi.org/10. $1108 / 20408741211244398$

Yi, S. W., Shun, C. W., Hsin, H. L., \& Yu, Y. W. (2011). The relationship of service failure severity, service recovery justice and perceived switching costs with customer loyalty in the context of e-tailing. International Journal of Information Management, 31(4), 350-359. http://dx.doi.org/10.1016/j.jinfomgt. 2010.09.001

Yi, W. F., Cheng, C. W., \& Wei, T. W. (2010). The impacts of online retailing service recovery and perceived justice on consumer loyalty. International Journal of Electronic Business Management, 8(3), 239-249.

Yunus, N. K. Y. (2009). Justice Oriented Recovery Strategies and Customer Retention in the Retail Banking Industry in Malaysia. International Review of Business Research Papers, 5(5), 212-228.

Zeithaml, V. A., Berry, L. L., \& Parasuraman, A. (1993). The Nature and Determinants of Customer Expectations of Service. Journal of the Academy of Marketing Science, 21, 1-12. http://dx.doi.org/10.1177/0092070393 211001

\section{Copyrights}

Copyright for this article is retained by the author(s), with first publication rights granted to the journal.

This is an open-access article distributed under the terms and conditions of the Creative Commons Attribution license (http://creativecommons.org/licenses/by/3.0/). 